\title{
Formulation and Optimization of Gentamicin Hydrogel Infused with Tetracarpidium Conophorum Extract via a Central Composite Design for Topical Delivery
}

\author{
Gentamisin Hidrojelinin Tetrakarpidium Conophorum Ekstraktı ile \\ Aşılanarak Formülasyonu ve Optimizasyonu
}

\author{
(D) Margaret Okonawan ILOMUANYA*, (D) Nosakhare Andrew AMENAGHAWON², (D) Joy ODIMEGWU³, (D) Omotunde Olufunke OKUBANJO', \\ (D) Chinelo AGHAIZU1, (D) Adeyinka OLUWATOBILOBA', (D) Thomas AKIMIEN', (D) Tolulope AJAYI' \\ 'University of Lagos, Faculty of Pharmacy, Department of Pharmaceutics and Pharmaceutical Technology, Lagos, Nigeria \\ 2University of Benin, Faculty of Engineering, Department of Chemical Engineering, Edo State, Nigeria \\ ${ }^{3}$ University of Lagos, Faculty of Pharmacy, Department of Pharmacognosy, Lagos, Nigeria
}

\begin{abstract}
Objectives: Response surface methodology coupled with statistically designed experiments has been found to be very useful in optimising multivariable processes. The aim of this study was to evaluate the influence of two independent variables, a ratio of permeation enhancers/ antioxidants (transcutol and ethanolic extract of tetracarpidium conophorum EETC) and stirring rate, on the flux and permeation of gentamicin hydrogel.

Materials and Methods: A modification of free radical initial polymerization was used to formulate the gentamicin hydrogel. A 32 factorial CCD was then used to investigate the effect of independent variables of the permeation enhancer transcutol: EETC (X1), stirring speed (X2) via 14 formulation batches, which were evaluated for dependent variables flux (Y1) and amount of drug permeated after 12 hours (Y2) ex vivo.

Results: The results of ANOVA performed to determine the fit of the models revealed that the models were statistically significant ( $p<0.05)$ and did not show lack of fit (R2>0.80). The regression equation generated for flux was $Y 1=19.35-25.82 X 1-0.044 X 2+0.0097 X 1 X 2+11.86 X 21$ and for cumulative permeation of gentamicin in 12 hours $Y 2=315.50-189.67 X 1+0.28 X 2-1.29 X 1 X 2+123.55 X 21$. The validity of the statistical models used for predicting flux and drug permeation was confirmed by conducting three confirmation experimental runs at the identified optimum conditions. The results showed that there was no significant difference between the experimental results and those predicted by the statistical models.

Conclusion: The excellent correlation between the predicted and measured values shows the validity of statistical models (R2=0.95). An antioxidant and permeation enhancer has been used for the first time to investigate the influence on dependent variables. Optimization of gentamicin hydrogel using central composite statistical design is valid for the prediction of drug permeation and flux using variables in formulation.
\end{abstract}

Key words: Hydrogels, polymer, Tetracarpidium conophorum, response surface methodology, gentamicin

öz

Amaç: İstatistiksel olarak tasarlanmış deneyler ile birleştirilmiş cevap yüzey metodolojisinin, çok değişkenli proseslerin optimize edilmesinde çok yararlı olduğu bulunmuştur. Bu çalışmanın amacı, iki bağımsız değişkenin, permeasyon arttırıcı/antioksidanların (transkutol ve tetrakarpidium conophorum EETC'nin etanolik ekstresi) ve karıştırma hızının, gentamisin hidrojelinin akışı ve permeasyonu üzerindeki etkisini değerlendirmektir.

Gereç ve Yöntemler: Gentamisin hidrojelini formüle etmek için serbest radikal başlangıç polimerizasyonunun modifikasyonu kullanıldı. Daha sonra, permeasyon arttırıcı transkutol: EETC (X1), karıştırma hızı (X2) bağımsız değișkenlerinin etkisini araştırmak için, bağımlı değişkenler, akıș (Y1) ve 12 saat ex vivo permeasyondan sonra elde edilen ilaç miktarı (Y2), için değerlendirilen, 14 formülasyon grubuyla, 32 faktöriyel merkez CCD kullanılmıștır.

*Correspondence: E-mail: milomuanya@unilag.edu.ng, Phone: +2348033295077 ORCID-ID: orcid.org/0000-0001-8819-1937

Received: 05.09.2017, Accepted: 19.10.2017

-Turk J Pharm Sci, Published by Galenos Publishing House. 
Bulgular: Modellerin uyumunu belirlemek için yapılan ANOVA sonuçları, modellerin istatistiksel olarak anlamlı olduğunu ( $p<0.05$ ) ve uyumsuzluk göstermediğini ortaya koymuştur (R2>0.80). Akış için olușturulan regresyon denklemi Y1=19.35 - 25.82X1 - 0.044X2 + 0.0097X1X2 + 11.86X21 idi ve 12 saatte gentamisinin kümülatif permeasyonu Y2=315.50 - 189.67X1 + 0.28X2 - 1.29X1X2 + 123.55X21 idi. Akış ve etkin madde permeasyonunu tahmin etmek için kullanılan istatistiksel modellerin geçerliliği, belirlenen optimum şartlarda üç doğrulama deneysel çalıșması ile onaylanmıştır. Sonuçlar, deney sonuçları ile istatistiksel modeller tarafından tahmin edilenler arasında anlamlı bir fark olmadığını göstermiștir.

Sonuç: Öngörülen ve ölçülen değerler arasındaki mükemmel korelasyon istatistiksel modellerin geçerliliğini göstermektedir (R2=0.95). Bağımlı değişkenler üzerindeki etkiyi araştırmak için ilk kez bir antioksidan ve geçirgenlik arttırıcı kullanılmıştır. Gentamisin hidrojelinin istatistiksel merkez esaslı kompozit tasarım kullanılarak optimizasyonu, formülasyondaki değișkenleri kullanarak etkin madde permesyonu ve akışın tahmin edilmesi için geçerlidir.

Anahtar kelimeler: Hidrojeller, polimer, Tetracarpidium conophorum, cevap yüzey metodolojisi, gentamisin

\section{INTRODUCTION}

Gentamicin is a water-soluble aminoglycoside antibiotic derived from Micromonospora purpurea, and actinomycete. It is used for the treatment of infections caused by susceptible strains of Pseudomonas aeruginosa, Proteus species (indole-positive and indole-negative), Escherischia coli, Klebsiella-EnterobactorSerratia species, Citrobacter species, and Staphylococcus species (coagulase-positive and coagulase-negative). When required for topical administration, it is usually formulated as creams as well as ointments, which possess various disadvantages in terms of reduced stability, erratic drug release, and decreased skin permeability when compared with hydrogels.

The water holding capacity and permeability are the most important characteristic features of a hydrogel. ${ }^{2}$ Biocompatibility is the third most important characteristic required by a hydrogel because it calls for compatibility of the gel with human natural tissue without causing any toxicity upon its degradation. ${ }^{2}$ In addition to the above characteristics, the soft and rubbery nature of hydrogels minimises irritation to surrounding tissue. Their highly porous structure, which can easily be tuned by controlling the density of the cross-links in the gel matrix and the affinity of the hydrogels for the aqueous environment in which they are swollen, ${ }^{3}$ is also an advantage. The porosity of hydrogels also permits loading of drugs into the gel matrix and subsequent drug release at a rate that is dependent on the diffusion coefficient of the small molecule or macromolecule through the gel network. ${ }^{3}$

Tetracarpidium conophorum, commonly called the African walnut plant, whose ethanolic extract would make up the second component of the formulation of study, is a perennial climbing shrub 10 to 20 feet high, found growing wild in forest zones of sub-Sahara Africa, including Nigeria. Studies have shown that the African walnut possess some beneficial antibacterial, ${ }^{4}$ antioxidant, ${ }^{4,5}$ and immune-stimulating properties. It is commonly used in Nigerian folkloric medicine for the treatment of bacterial infections and ailments caused by oxidative stress. ${ }^{6}$ Photochemical screening of ethanolic extracts of Tetracarpidium conophorum showed presence of alkaloids, saponins, glycosides, flavonoids, and tannins in studies by Ezealisiji et al. ${ }^{6}$ The antibacterial properties of this plant extract can be attributed to the presence of these secondary metabolites. By incorporating these extracts into a three-dimensional polymer network formed by hydrophilic polymer chains via either physical or chemical bonds, hydrogels will be used to form a novel drug delivery system comprising components that will work synergistically to facilitate wound healing. ${ }^{\text {? }}$

In the development of a topical dose form, an important issue was to design an optimized pharmaceutical formulation with an appropriate penetration rate within a short time period with minimum trials. Traditional experiments require more effort, time, and materials when a complex formulation needs to be developed. Recently, response surface methodology (RSM) via central composite design (CCD) coupled with statistically designed experiments has been found to be very useful in optimising multivariable processes and it has been successfully applied to the optimisation of many bioprocesses. ${ }^{8-11}$ Based on the principle of design of experiments, the methodology encompasses the use of various types of experimental designs, generation of polynomial equations, and mapping of the response over the experimental domain.

In this investigation, we explored the utility of RSM via CCD for the optimization of topical gentamicin hydrogel production using a two variable CCDs via free radical initial polymerization of the alkyl acrylate polymer. The developed optimised formulation was evaluated for performance-related in vitro drug release and ex vivo permeation study. Physicochemical characterization of the gel was conducted via rheologic studies, drug content evaluation, Fourier-transform infrared spectroscopy (FTIR), and the mechanism of release was evaluated via varying kinetic models.

\section{EXPERIMENTAL}

\section{Chemical and reagents}

Gentamicin sulphate (BP grade) was obtained as a gift from Drugfield Pharmaceuticals Limited (Ogun State, Nigeria), Carbopol Ultrez $2{ }^{\circledR}$ was obtained as a gift from Metchem Limited (Mumbai India/Lubrizol Corporation, USA), Carbopol 940 ${ }^{\circledR}$ (Lubrizol Corporation, USA), propylene glycol, triethanolamine (TEA) (Merck Germany), Transcutol ${ }^{\circledR}$ was obtained as a gift from Gattefosse (Cedex, France), 0-Phthalaldehyde OPA from Fluka (Steiheim Germany). N-acetyl cysteine ( $\mathrm{NaC}$ ) sodium hydroxide was from Sigma Aldrich (St. Louis, USA). All other chemical and reagents were of analytical grade.

\section{Extraction of ethanolic extract of Tetracarpidium conophorum} (EETC)

The plant was collected from farms in Nkwere Local Government Area, Imo state, Nigeria, and identified by Mr Oyebanji 0.0 of 
the Department of Botany, University of Lagos, Lagos, Nigeria. A voucher specimen assigned reference number LUH6972 was deposited in the institutional herbarium for reference.

The methanolic extract of the leaves was obtained using a method by Amaeze et al., ${ }^{5}$ 2011. The plants were air dried for 14 days and the leaves were separated and ground using a Retsch rotor mill ZM 200. Two hundred grams of the finely ground leaves of $T$. conophorum were weighed and placed in a container with 2 litres of ethanol and allowed to macerate for $24 \mathrm{hrs}$, and then filtered. The extraction was performed three times and the combined filtrate was centrifuged at $3000 \mathrm{rpm}$ using a Sorvall ST 8 centrifuge. The EETC obtained was freeze dried, transferred into a glass vial, and kept in a desiccator at $20^{\circ} \mathrm{C}$ until analysis.

\section{Preparation of gentamicin-loaded acrylate copolymer based hydrogels}

Gentamicin sulphate $(0.1 \% \mathrm{w} / \mathrm{w})$ was dissolved in aliquots of purified water and propylene glycol was titrated in drops into the mixture. The permeation enhancer Transcutol:EETC (antioxidant extract) in varying ratios $2 \% \mathrm{v} / \mathrm{v}$ and $10 \% \mathrm{v} / \mathrm{v}$ propylene glycol were incorporated into the aqueous phase of the formulation. At $25^{\circ} \mathrm{C}$, the gel phase was prepared by dispersing the alkyl acrylate cross-polymers Carbopol ${ }^{\circledR}$ Ultrez $21(1.5 \% \mathrm{w} / \mathrm{v})$ in purified water using a mechanical stirrer at a predetermined stirring rate. The $\mathrm{pH}$ was adjusted with the cross-linking agent TEA to a $\mathrm{pH}$ of 5.5. Both the aqueous fraction and the gel fraction were then mixed at a varying stirring rates to form the polymeric hydrogel. The hydrogels were stored in sealed glass containers for further analysis.

\section{FTIR}

Gentamicin, EETC, and Carbopol Ultez $21^{\circledR}$ compatibility was evaluated using FTIR. Physical mixtures of gentamicin, the polymers (Carbopol Ultrez 21) and excipients (1:1) were separately mixed with three parts of potassium bromide and compressed to form pellets with a hydraulic press at 10 tons' pressure. The FTIR absorption spectra of all samples were recorded in the range of $400-4000 / \mathrm{cm}$ using the potassium bromide disc method with FTIR spectroscopy (Bruker, South Africa). The optimized hydrogel formulation was also analysed via FTIR. The physical appearance of the samples and the appearance (or disappearance) of peaks in the spectra were observed to access any possible physical or chemical interactions.

\section{Experimental design}

A two-variable, CCD was used for the formulation of the gentamicin hydrogels. The independent variables tested included the Transcutol:EETC ratio and stirring speed. These variables were varied over five levels and replicated six times at the centre point to result in a total of fourteen experimental runs. The ranges of the independent variables are shown in Table 1. Two responses, namely flux $\left(\mu \mathrm{g} / \mathrm{cm}^{2} / \mathrm{hr}\right)$ and the amount of drug permeated after 12 hours $\left(\mu \mathrm{g} / \mathrm{cm}^{2}\right)$ were chosen for optimisation using RSM. The experimental observations were analysed using Design Expert ${ }^{\circledR} 7.0 .0$ software (Stat-ease,
Inc. Minneapolis, USA). The coded and actual values of the independent variables were calculated using Equation (1).

$X_{i}=\frac{X_{i}-X_{0}}{\Delta X_{i}}$

Where $X_{i}$ and $X_{i}$ are the coded and actual values of the independent variable, respectively. $X_{0}$ is the actual value of the independent variable at the centre point and $\Delta X_{i}$ is the step change in the actual value of the independent variable. The experimental data was fitted according to Equation (2) as a second-order polynomial equation including the main effects and interaction effects of each variable. One-way analysis of variance (ANOVA) and response surface plots were generated using Design Expert and the optimised value of the independent variables for optimum response was determined using numerical optimisation.

$$
Y_{i}=b 0+\sum b_{i} X_{j}+\sum b_{i j} X_{i} X_{i}+\sum b_{i i} X_{i}^{2}+e_{i}
$$

where $Y_{i}$ is the dependent variable or predicted response, $X_{i}$ and $X_{j}$ are the independent variables, $b_{0}$ is offset term, $b_{i}$ and $b_{i j}$ are the single and interaction effect coefficients, and $e_{i}$ is the error term.

\section{Physical evaluation of hydrogel formulation}

The hydrogels were physically examined for colour, homogeneity, and consistency.

\section{pH evaluation}

The $\mathrm{pH}$ of the hydrogels was recorded using a $\mathrm{pH}$ meter (Ashford, UK), ensuring that the electrode was in contact with the formulated hydrogel for 45 seconds to allow for equilibration. Experiments were performed in triplicate.

\section{Rheologic studies}

The viscosities of the varying formulations were determined at $25^{\circ} \mathrm{C}$ at varying rpm with the aid of a cone and plate viscometer with spindle-4, (Brookfield Engineering Laboratories, DV-E Digital viscometer ID:12020N15).

\section{Drug content determination}

One gram of hydrogel was dissolved in $10 \mathrm{~mL}$ of water, centrifuged at $500 \mathrm{rpm}$ for 45 mins, and filtered using a $0.5-\mu \mathrm{m}$ millipore filter. Using a 1:50 dilution, the concentration of gentamicin was obtained using a ultraviolet (UV)/visible spectrophotometer (UV-Vis 2600 Shimadzu Analytical and measuring instruments) after derivatisation using 0 -Phthalaldehyde reagent with Kowalczuk's method. ${ }^{(12)}$ Phthalaldehyde reagent was formulated prior to use by dissolving $20 \mathrm{mg}$ of O-Phthalaldehyde in 1.0

\section{Table 1. Experimental range of independent variables for a two} factor $C C D$

\begin{tabular}{|c|c|c|c|c|c|c|}
\hline \multirow{2}{*}{$\begin{array}{l}\text { Independent } \\
\text { variables }\end{array}$} & \multirow{2}{*}{ Symbols } & \multicolumn{5}{|c|}{ Coded and actual levels } \\
\hline & & -1.414 & -1 & 0 & 1 & 1.41 \\
\hline Transcutol:EETC (-) & $X_{1}$ & $1 / 3$ & $3 / 7$ & $2 / 3$ & 0.902 & 1 \\
\hline Stirring speed (rpm) & $X_{2}$ & 60 & 77.57 & 120 & 162.43 & 180 \\
\hline
\end{tabular}

EETC: Ethanolic extract of Tetracarpidium conophorum, CCD: Central composite design 
$\mathrm{mL}$ of methanol to $1.5 \mathrm{~mL}$ of a $10 \% \mathrm{NaC}$ and diluting to $10 \mathrm{~mL}$ with $0.2 \mathrm{~mL}^{-1}$ solution of borate buffer $(\mathrm{pH} 10)$. Gentamicin, an aminoglycoside antibiotic, does not absorb UV light due to its weak chromophore, hence the need for derivatisation. The phthalaldehyde reagent was stored in amber-coloured bottles and kept in a dark cupboard prior to use. The reaction of the amine group in the aminoglycoside with the O-Phthalaldehyde in the presence of $\mathrm{NaC}$ yields a fluorescent isoindole which is measured at $332 \mathrm{~nm}$ absorbance. ${ }^{12}$ This method is superior to that used by Nnamani et al., where mercaptoethanol, emits a characteristic unpleasant odour during the derivatization process.

\section{Preparation of wistar rat abdominal skin}

The hair of ether anesthetized Wistar rats weighing between 150-200 g was carefully removed with electric clippers, and the full thickness of skin was removed from the abdominal region. The epidermis was prepared surgically using a heat separation technique, ${ }^{13}$ which involved soaking the entire abdominal skin in water at $60^{\circ} \mathrm{C}$ for $45 \mathrm{~s}$, followed by careful removal of the epidermis. The epidermis was washed three times with water and used for ex vivo permeability studies.

\section{Ex vivo permeation studies}

Permeation studies were performed using skin obtained from the rats (skin thickness $0.45-0.8 \mathrm{~mm}$ ) mounted on modified Franz diffusion cells with a diffusion area of $3.71 \mathrm{~cm}^{2}$. The receptor compartment contained $30 \mathrm{~mL}$ phosphate buffer $(\mathrm{pH}$ of 7.4 at $37.1^{\circ} \mathrm{C} \pm 0.2^{\circ} \mathrm{C}$ ). One gram of each hydrogel formulation was applied on the skin surface in the donor compartment area with the stratum corneum facing downwards. An aliquot of $1 \mathrm{~mL}$ was withdrawn at predetermined time intervals and replaced with an equal volume of fresh media. The samples were analysed using a UV/visible spectrophotometer (UV-Vis 2600 Shimadzu Analytical and measuring instruments) after derivatisation using O-Phthalaldehyde reagent. Absorbance was measured at $332 \mathrm{~nm}$. All experiments were performed in triplicate.

Cumulative amounts of permeated drug $\left(\mu \mathrm{g} / \mathrm{cm}^{2}\right)$ was plotted against time in hours and $\mathrm{drug}\left(\mathrm{\mu g} / \mathrm{cm}^{2} / \mathrm{hr}\right)$ at steady state was calculated by dividing the slope of the linear portion of the curve by the area of the exposed skin surface $\left(3.71 \mathrm{~cm}^{2}\right)$. The permeation coefficient was deduced by dividing the flux by initial drug load as shown in Equations 3 and 4:

$P E c=\delta Q(A \delta t)^{-1} / C o$

$P E c=J s s / C o(c m / h r)$

where PEc is the permeation coefficient $\left(\mathrm{cm} / \mathrm{hr}^{-1}\right)$; Co is the initial drug concentration in the drug compartment: Jss represents the steady state flux $\left(\mu \mathrm{g} / \mathrm{cm}^{2} / \mathrm{hr}\right)$, where $Q$ indicates the quantity of substances crossing the rat skin, $A$ is the area of the rat skin exposed, and $t$ is the time of exposure in hours.

The optimised gentamicin hydrogel derived from statistical analysis was then compared with a marketed gentamicin formulation via ex vivo permeation studies and the data obtained were evaluated using ANOVA followed by Tukeys test at $p<0.05$.

\section{Ex vivo permeation kinetics of drug release}

The mechanism of drug release from the hydrogels was analysed by fitting the release data to various release kinetic models. The zero-order (Ko), first order (Kf), and Korsemeyer-Peppas model was used to determine the model with the best fit.1.11

\section{Accelerated stability testing}

The International Council for Harmonisation of Technical Requirements for Pharmaceuticals for Human Use (ICH) guidelines $\left(40^{\circ} \mathrm{C} / 75 \% \mathrm{RH}\right)$ were followed in the accelerated stability testing of the optimised hydrogel formulation. The hydrogels were packed in amber-coloured jars and kept in a stability chamber with a set temperature and relative humidity. The formulations were subjected to accelerated stability testing at both room temperature and at $40^{\circ} \mathrm{C}$ and parameters were recorded on day $0,10,15,30$, and 90 . The formulations were evaluated for $\mathrm{pH}$, assay, gel index (Gl), and percentage of drug released at 12 hours.

The study was approved by the College of Medicine, University of Lagos Health Research Ethics Committee (CMULHREC number: CMUL/HREC/04/17/117, 15.04.2015).

\section{Statistical analysis}

The data were expressed mean standard deviation $( \pm S D)$ using ANOVA ( $\pm S D$ ). Significant differences $(p<0.05)$ of mean values were determined using the Tukey test.

\section{RESULTS}

\section{FTIR spectroscopy}

The individual spectra and the physical mixture spectra were recorded and analysed. The finger print region and absorbance values relating to the relevant bioactive functional groups of the individual spectra analysed and the physical mixtures showed an absence of interaction between gentamicin, carbopol, and Transcutol and EETC as shown in Figure 1. Absorbance patterns corresponding in position and relative intensity to those in the FTIR spectra of the individual components were observed with no significant change in FTIR spectra after introduction of the polymers and the permeation enhancers, thus indicating a lack of physical or chemical interaction, as shown in Figure 1.

Some major bands/peaks on the spectra were $3089.75 \mathrm{~cm}^{-1} \mathrm{O}-\mathrm{H}$ stretching, $1706.88 \mathrm{~cm}^{-1}$ carboxyl group, which is characteristic of the principal absorption peaks of Carbopo $^{\oplus}$. Gentamicin was characterized by principal peaks at $610.22 \mathrm{~cm}^{-1}$ and $1100-$ $1400 \mathrm{~cm}^{-1}$. The spectral data of EETC confirmed the presence of functional groups such as hydroxyl, an ester group and an aldehyde group among others $2920.21 \mathrm{~cm}^{-1}-\mathrm{C}-\mathrm{H}$ stretching depicting alkenes and aryl groups, $1730.32 \mathrm{~cm}^{-1}$ - aldehyde/ ketone $-\mathrm{C}=\mathrm{C}$ - stretching at $1440 \mathrm{~cm}^{-1}$. For the compatibility study, the FTIR spectra were compared and there was no disappearance or major shift of important peaks in the physical mixtures of Carbopol $^{\circledR}$, EETC, and Transcutol spectra.

\section{Gel characterization}

All formulations had a pale greenish colour and a good gellike consistency. The hydrogels formulated using the CCD had 


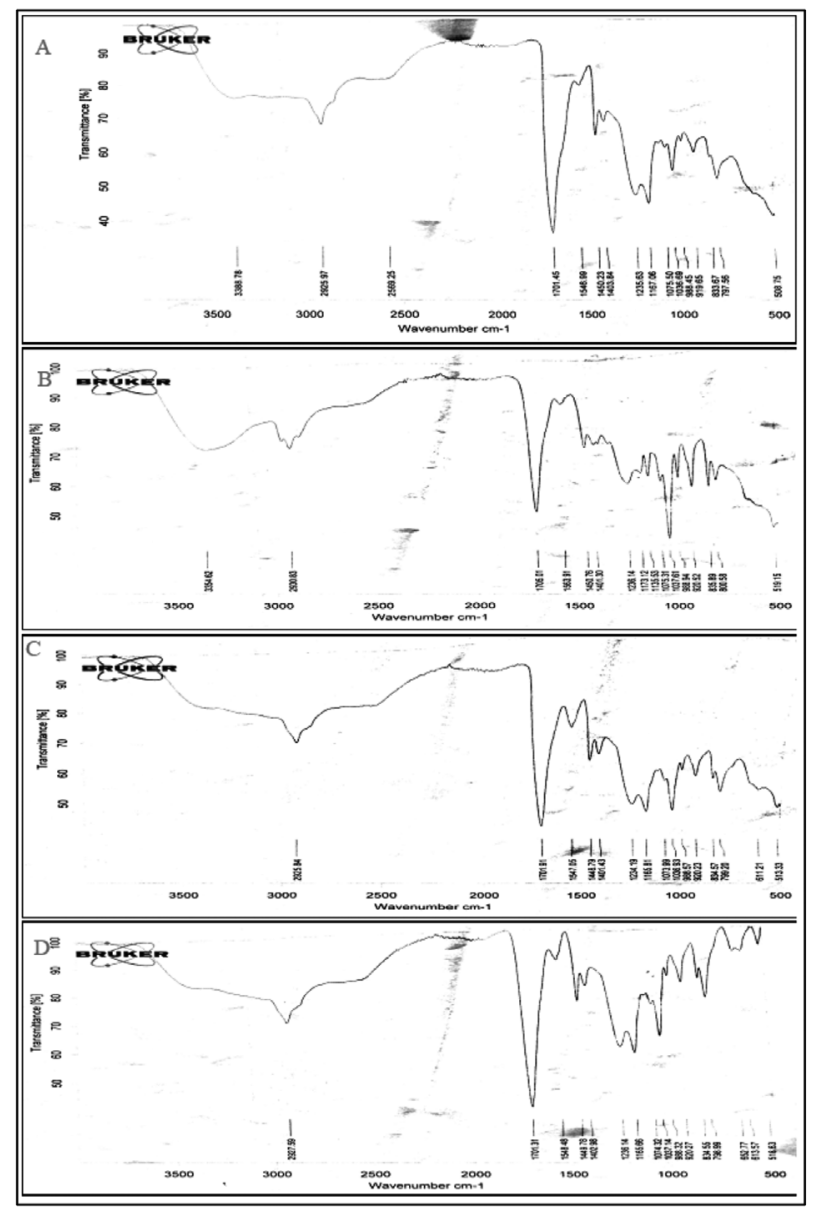

Figure 1. Fourier-transform infrared spectroscopy peaks of A) Gentamicin and the physical mixtures of $\mathrm{Carbopo}^{\circledR}(\mathrm{B})$ Physical mixtures of $\mathrm{Carbopo}^{\circledR}$ and EETC, (C) Physical mixtures of Carbopol ${ }^{\circledR}$ and EETC:Transcutol (D) Hydrogel formulation containing $\mathrm{Carbopol}^{\circledR}$, EETC Transcutol and all other excipients drug content variation form $94.5 \%-102.9 \%$ had excellent ex vivo permeation profiles, $\mathrm{GeH} 11$ had $258.06 \mu \mathrm{g} / \mathrm{cm}^{2} \pm 0.43$ of gentamicin permeated at eight hours in as seen in Figure 2. The $\mathrm{pH}$ of all the 14 hydrogel formulations ranged of 5.50-5.95 after neutralization with TEA as shown in Table 2 . This $\mathrm{pH}$ range is important for use on the surface of wounds to facilitate wound healing at an acidic $\mathrm{pH}^{1,3}$

\section{Rheologic measurements}

Spindle 4 was used for the viscometric characterisation of the hydrogels. Characterisation was performed at 20-60 rpm, which is the working range for this spindle. As the shear rate increased there was a corresponding decrease in the viscosity of the gels. This was evaluated exponentially using the Power Law as shown in Equation 3.

$\mathrm{T}=\mathrm{K} \mathrm{D}^{\mathrm{n}}$

where $T$ is shear stress, $K$ is $G$ l or consistency index, $D$ is shear rate, and $\mathrm{n}$ is fow index. Gel indices computed ranged from 1.02 to 2.11 as shown in Table 2 .

\section{Statistical modelling and analysis}

Analysis of the experimental data using the Design Expert software revealed that the quadratic model was suitable for describing the formulation of the hydrogels. The final statistical models for predicting the flux and the amount of drug permeated after 12 hours are given in Equations 6 and 7.

$Y=19.35-25.82 X_{1}-0.044 X_{2}+0.0097 X_{1} X_{2}+11.86 X_{1}^{2}$

$Y=31.50-189.67 X_{1}-0.28 X_{2}+1.29 X_{1} X_{2}+123.55 X_{1}^{2}$

The values of the responses as predicted by Equations 4 and 5 are presented in Table 3 alongside the experimental data for comparison. The results of ANOVA conducted to determine the fit of the statistical models for flux and drug permeation are presented in Tables 3, 4, and 5.

Table 2. Observed responses in the central composite design for gentamicin hydrogels

\begin{tabular}{|c|c|c|c|c|c|c|c|}
\hline \multirow{2}{*}{$\begin{array}{l}\text { Hydrogel } \\
\text { formulation }\end{array}$} & \multirow{2}{*}{$\mathrm{pH}$} & \multirow{2}{*}{ Assay (\%) } & \multirow{2}{*}{$\mathrm{PEc}(\mathrm{cm} / \mathrm{hr})$} & \multirow{2}{*}{ Gel index } & \multicolumn{3}{|c|}{ Kinetic modelling } \\
\hline & & & & & Zero-order (Ko) & First-order (Kf) & Higuchi model (Kh) \\
\hline GeH 1 & $5.67 \pm 0.05$ & $98.65 \pm 0.11$ & 1.77 & 1.02 & 0.912 & 0.567 & 0.943 \\
\hline GeH 2 & $5.69 \pm 0.04$ & $98.73 \pm 0.28$ & 1.91 & 1.76 & 0.893 & 0.329 & 0.954 \\
\hline $\mathrm{GeH} 3$ & $5.78 \pm 0.32$ & $99.43 \pm 0.78$ & 1.72 & 1.89 & 0.903 & 0.510 & 0.964 \\
\hline GeH 4 & $5.51 \pm 0.09$ & $101.02 \pm 0.21$ & 1.85 & 1.76 & 0.911 & 0.622 & 0.932 \\
\hline GeH 5 & $5.86 \pm 0.03$ & $98.82 \pm 0.88$ & 1.70 & 1.65 & 0.954 & 0.476 & 0.954 \\
\hline GeH 6 & $5.54 \pm 0.48$ & $99.72 \pm 0.01$ & 1.69 & 1.97 & 0.963 & 0.619 & 0.922 \\
\hline $\mathrm{GeH} 7$ & $5.88 \pm 0.11$ & $100.07 \pm 0.29$ & 1.73 & 1.56 & 0.945 & 0.409 & 0.973 \\
\hline GeH 8 & $5.89 \pm 0.77$ & $98.99 \pm 0.89$ & 1.71 & 2.00 & 0.953 & 0.743 & 0.917 \\
\hline GeH 9 & $5.61 \pm 0.37$ & $98.62 \pm 0.67$ & 1.77 & 1.97 & 0.944 & 0.599 & 0.972 \\
\hline GeH 10 & $5.92 \pm 0.11$ & $99.89 \pm 0.32$ & 1.78 & 1.56 & 0.891 & 0.421 & 0.954 \\
\hline GeH 11 & $5.93 \pm 0.07$ & $100.33 \pm 0.06$ & 1.93 & 2.11 & 0.932 & 0.511 & 0.911 \\
\hline GeH 12 & $5.55 \pm 0.32$ & $101.77 \pm 0.03$ & 1.72 & 1.99 & 0.894 & 0.613 & 0.919 \\
\hline GeH 13 & $5.63 \pm 0.04$ & $102.31 \pm 0.15$ & 1.73 & 1.34 & 0.843 & 0.412 & 0.963 \\
\hline GeH 14 & $5.78 \pm 0.12$ & $100.99 \pm 0.45$ & 1.72 & 1.69 & 0.909 & 0.592 & 0.951 \\
\hline
\end{tabular}


Tables 3, 4, 5, and 6 show the results of ANOVA conducted to determine the fit of the statistical models representing the flux and drug permeation after twelve hours. Tables 3 and 4 show that the models for flux and drug permeation were statistically significant with very low p values of 0.0001 and 0.0019 , respectively. The single-effect model terms representing the effect of Transcutol:EETC ratio and stirring speed for both models (Equations 5 and 6) were significant indicating changes in the values of these variables could affect the flux and drug permeation.

Table 5 shows that the models for flux and drug permeation had high $R^{2}$ values of 0.90 and 0.82 , respectively. The $R^{2}$ value indicates the degree to which a model is able to predict a response. The closer the $R^{2}$ value is to unity, the better

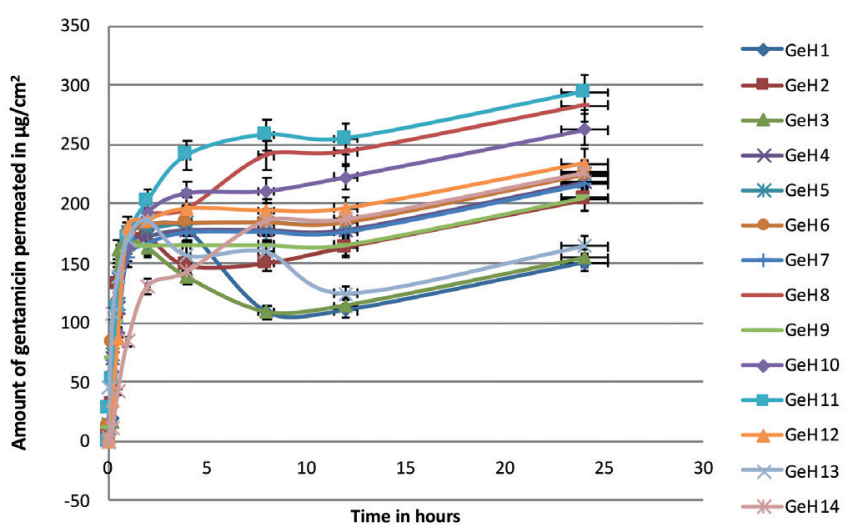

Figure 2. Ex vivo permeation profile of the varying gentamicin hydrogel formulations GeH 1-GeH 14 the model can predict the response..$^{14,15}$ The high $R^{2}$ values obtained for both models show that there was significant fit between the observed and predicted values of flux and drug permeation. Table 5 also shows that the SD of the observations was relatively small compared with the mean values of flux and drug permeation showing that there was very little dispersion about the mean for the data predicted by both models. The experimental runs were performed with high reliability and precision as seen from the relatively low values of coefficient of variation obtained for flux and drug permeation ( 8.75 and 12.27, respectively). ${ }^{16}$ The adequate precision values of both models were greater than four. This shows that the models had adequate signals and thus could be used to navigate the design space. ${ }^{17}$

\section{Effect of independent variables on hydrogel formulation}

Figures 3 and 4 are response surface plots showing the effect of Transcutol:EETC ratio and stirring speed on the flux and

\begin{tabular}{llllll}
\multicolumn{6}{c}{ Table 4. ANOVA results for model representing flux } \\
Sources & $\begin{array}{l}\text { Sum of } \\
\text { squares }\end{array}$ & df & $\begin{array}{l}\text { Mean } \\
\text { squares }\end{array}$ & F value & p value \\
\hline Model & 59.92 & 4 & 14.98 & 20.71 & 0.0001 \\
\hline$X_{1}$ & 35.41 & 1 & 35.41 & 48.94 & $<0.0001$ \\
\hline$X_{2}$ & 21.18 & 1 & 21.18 & 29.28 & 0.0004 \\
\hline$X_{1} X_{2}$ & 0.038 & 1 & 0.038 & 0.053 & 0.8238 \\
\hline$X_{1}^{2}$ & 3.29 & 1 & 3.29 & 4.55 & 0.0617 \\
\hline
\end{tabular}

ANOVA: Analysis of variance

Table 3. Experimental design matrix for gentamicin hydrogel formulation

Factors

\begin{tabular}{|c|c|c|c|c|c|c|c|c|}
\hline \multirow[t]{2}{*}{ Run } & \multicolumn{2}{|c|}{ Coded values } & \multicolumn{2}{|c|}{ Actual values } & \multicolumn{2}{|c|}{ Flux $\left(\mu \mathrm{g} / \mathrm{cm}^{2} / \mathrm{hr}\right)$} & \multicolumn{2}{|c|}{ Drug permeation $\left(\mu \mathrm{g} / \mathrm{cm}^{2}\right)$} \\
\hline & $x_{1}$ & $\mathrm{X}_{2}$ & $x_{1}$ & $\mathrm{X}_{2}$ & Actual & Predicted & Actual & Predicted \\
\hline $\mathrm{GeH} 1$ & 1 & 1 & 0.902 & 162.43 & 6.91 & 6.37 & 124.43 & 102.10 \\
\hline $\mathrm{GeH} 2$ & 1 & -1 & 0.902 & 77.57 & 9.25 & 9.43 & 186.93 & 176.70 \\
\hline GeH 3 & -1.414 & 0 & $1 / 3$ & 120.00 & 12.75 & 13.64 & 222.4 & 249.07 \\
\hline $\mathrm{GeH} 5$ & 0 & 0 & $2 / 3$ & 120.00 & 9.8 & 9.34 & 178.02 & 175.02 \\
\hline $\mathrm{GeH} 6$ & 0 & -1.414 & $2 / 3$ & 60.00 & 11.21 & 11.64 & 196.26 & 209.49 \\
\hline $\mathrm{GeH} 7$ & 0 & 0 & $2 / 3$ & 120.00 & 8.57 & 9.34 & 163.78 & 175.02 \\
\hline $\mathrm{GeH} 8$ & 1.414 & 0 & 1 & 120.00 & 7.63 & 7.69 & 114.21 & 128.71 \\
\hline GeH 11 & -1 & 1 & $3 / 7$ & 162.43 & 11.51 & 10.38 & 243.99 & 213.06 \\
\hline GeH 12 & 0 & 0 & $2 / 3$ & 120.00 & 9.98 & 9.34 & 183.99 & 175.02 \\
\hline GeH 13 & 0 & 0 & $2 / 3$ & 120.00 & 9.82 & 9.34 & 176.43 & 175.02 \\
\hline GeH 14 & 0 & 0 & $2 / 3$ & 120.00 & 9.05 & 9.34 & 165.34 & 175.02 \\
\hline
\end{tabular}


Table 5. ANOVA results for model representing drug permeation

\begin{tabular}{llllll} 
Sources & $\begin{array}{l}\text { Sum of } \\
\text { squares }\end{array}$ & df & $\begin{array}{l}\text { Mean } \\
\text { squares }\end{array}$ & F value & $p$ value \\
\hline Model & 20265.19 & 4 & 5066.30 & 10.50 & 0.0019 \\
\hline$X_{1}$ & 14486.89 & 1 & 14486.89 & 30.02 & 0.0004 \\
\hline$X_{2}$ & 4753.28 & 1 & 4753.28 & 9.85 & 0.0120 \\
\hline$X_{1} X_{2}$ & 667.96 & 1 & 667.96 & 1.38 & 0.2695 \\
\hline$X_{1}^{2}$ & 357.05 & 1 & 357.05 & 0.74 & 0.4120 \\
\hline
\end{tabular}

ANOVA: Analysis of variance

drug permeation of the hydrogels, respectively. Lower levels of stirring speed and transcutol:EETC ratio enhanced the flux of the formulated hydrogel as shown in Figure 3. This is evidenced by the fact that the flux increased with a reduction in stirring speed. This observation was recorded at all values of Transcutol:EETC ratio investigated. A similar trend was also observed for the Transcutol:EETC ratio for all values of stirring speed investigated.

\section{DISCUSSION}

Gentamicin is freely soluble in water (hydrophilic) and much of the drug was present in the aqueous phase of the formulations, loosely attached at or near the particle surface, because the more hydrophilic the substance, the weaker the interaction with particle surface, and eventually the compound could be localized in the surfactant layer. When more drug particles at the periphery of the particle surface eventually encounter the polymeric cross-linked gel-matrices, stabilization would occur. 18,19 Maximisation of skin uptake and delivery of a drug that is hydrophilic such as gentamicin in a hydrogel would thus be affected by increased stirring speeds above 60-77 rpm. Figure 4 shows that the drug permeation after twelve hours reduced with an increase in stirring speed. This trend was, however, more significant at a higher ratio of Transcutol to EETC compared with when the lower ratio was used. An increase of stirring speed above this point will ensure decreased porosity of the polymeric system increasing entrapment of the Transcutol:EETC within the hydrophilic matrix due to excessively intense agitation during formulation. This may consequently result in decreased release rates as seen in Figure 2 and 4, inadvertently negatively influencing permeation of gentamicin through the skin as seen in Figure 4.' A burst effect as result of increase stirring speed may also account for the decreased drug permeation with an increase in stirring speed as the drug is freed from the polymeric matrices and as such cannot be transported through the biologic membrane using transcutol:EETC. This effect will account for why there is a reduced flux at higher stirring speeds, as shown in Table 3 , where the experimental values were closely correlated with the predicted responses.

EETC has been studied for toxicity and biocompatibility and has been seen to be nontoxic to and biocompatible with mammalian cell lines, thus informing its use in this formulation

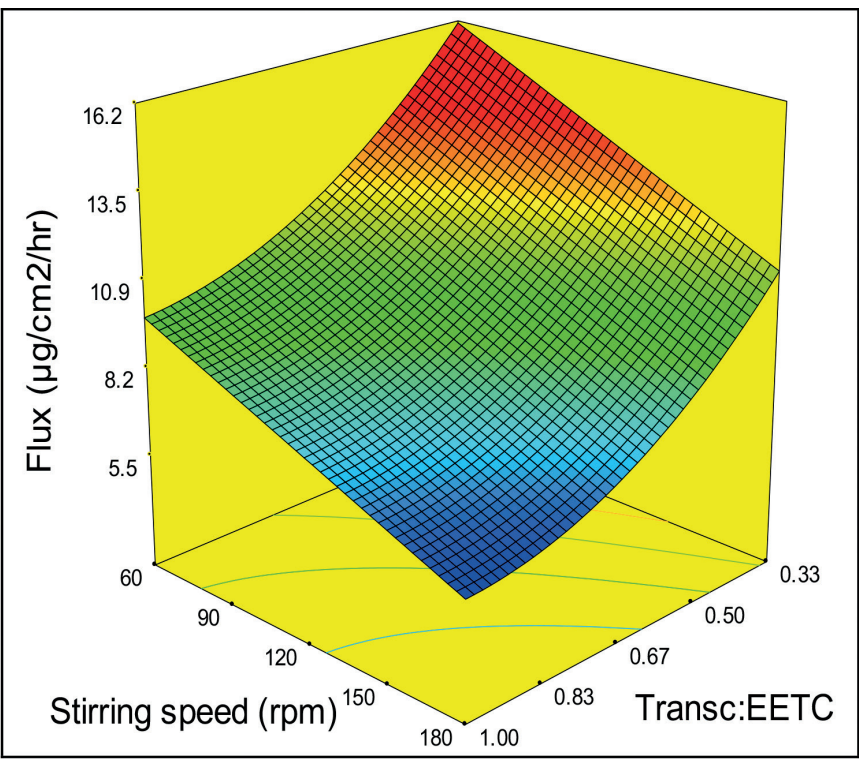

Figure 3. Effect of Transcutol:EETC ratio and stirring speed on flux

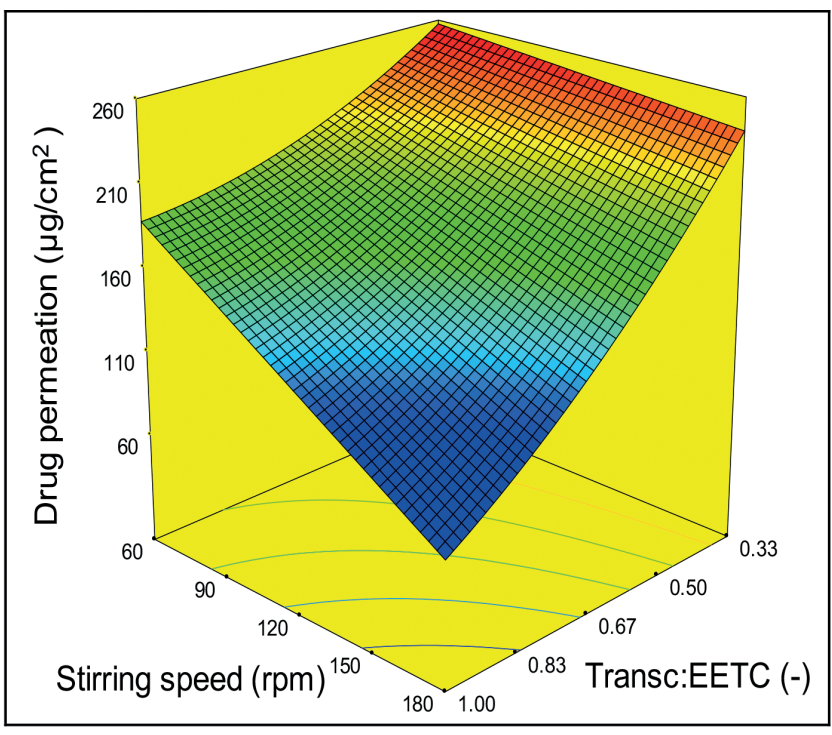

Figure 4. Effect of Transcutol:EETC ratio and stirring speed on drug permeation after 12 hours

development. ${ }^{4-6}$ EETC is very high in antioxidants, which lower inflammatory markers and facilitate wound healing by promoting fibroblast migration. This combination of EETC with transcutol (2-(2-Ethoxyethoxy)ethanol), a chemical permeation enhancer, synergistically causes diffusional resistance of the stratum corneum, thereby increasing migration of gentamicin through the skin via increased solubility in the stratum corneum. Transcutol:EETC at high concentrations facilitates interaction with stratum corneum lipids to increase fluid into the skin producing increased flux, $\mathrm{Pec}$, and ultimately drug permeation. There was an inverse relationship between the drug permeation after twelve hours and the transcutol:EETC ratio. This ensures that increased permeation occurs in the first 
12 hours of hydrogel application. The flux obtained ranging from 9.05 to $14.42 \mu \mathrm{g} / \mathrm{cm}^{2} / \mathrm{hr}$ (accounting for release at the linear portion of the gentamicin permeation curve in Figure 1, which represents the first 4 hours of drug release and permeation) showed that $\mathrm{GeH} 4$ with flux $14.42 \mu \mathrm{g} / \mathrm{cm}^{2} / \mathrm{hr}$ had the highest flux, which reflects increased permeation at an optimal stirring speed. This trend was observed both at high as well as at low values of stirring speed. However, the correlation between the drug permeation and transcutol:EETC ratio was more significant at high values of stirring speed due to the increased porosity of the hydrogel matrix. The mechanism of release predominantly observed was the Higuchi model, thus relating that the initial drug concentration in the hydrogel matrix was much higher than drug solubility with drug diffusion taking place in one dimension with edge effect being negligible, this accounts for increased release through pores in the matrix hydrogel system.

\section{Optimisation of hydrogel formulation}

Numerical optimization was performed to maximize the flux and drug permeation using the Design Expert software. The optimum conditions were chosen from the results obtained

Table 6. Statistical information for ANOVA

\begin{tabular}{lll} 
& \multicolumn{2}{c}{ Response } \\
\cline { 2 - 3 } & Flux & Drug permeation \\
\hline R-squared & 0.90 & 0.82 \\
\hline Mean & 9.72 & 178.98 \\
\hline Standard deviation & 0.85 & 21.97 \\
\hline C.V \% & 8.75 & 12.27 \\
\hline Adeq. precision & 14.68 & 11.20 \\
\hline
\end{tabular}

ANOVA: Analysis of variance

Table 7. Summary of optimum conditions for the formulation of hydrogels

\begin{tabular}{ll} 
Variables & Optimum value \\
\hline Stirring speed (rpm) & 60 \\
\hline Transcutol:EETC ratio $(-)$ & $1 / 3$ \\
\hline Flux $\left(\mu \mathrm{g} / \mathrm{cm}^{2} / \mathrm{hr}\right)$ & 16.1 \\
\hline Drug permeation after 12 hours $\left(\mu \mathrm{g} / \mathrm{cm}^{2}\right)$ & 258 \\
\hline
\end{tabular}

EETC: Ethanolic extract of Tetracarpidium conophorum from the software possessing the highest desirability. These conditions are summarized in Table 6 . The implication of these results is that the maximum flux and drug permeation can only be obtained if the independent variables are fixed at the values shown in Table 7. Accelerated stability testing of the optimized formulation showed that no variation in $\mathrm{pH}$, assay, gel index, percentage of drug released at 12 hours was observed, as shown in Table 8.

\section{Validation of statistical models}

The validity of the statistical models used for predicting flux and drug permeation was confirmed by conducting three confirmation experimental runs at the identified optimum conditions (Table 6 ). The results showed that there was no significant difference between the experimental results and those predicted by the statistical models. The excellent correlation between the predicted and measured values shows the validity of the statistical models. Figure 5 shows the percentage of drug released from the optimised formulation in comparison with a marketed formulation. The ex vivo permeation study showed an improved release rate was obtained compared with the marketed topical formulation with $100 \%$ release occuring at 12 hours with a significant effect $(p<0.05)$ compared with the marketed brand, which had $90 \%$ release at the same time point. This result is in consonance with the optimum value of drug permeation given in Table 7 . Flux was obtained as $16.9 \mu \mathrm{g} / \mathrm{cm}^{2} /$ $\mathrm{hr}$ compared with $9.98 \mu \mathrm{g} / \mathrm{cm}^{2} / \mathrm{hr}$ for the marketed formulation, and the amount of drug permeated after 12 hours was $260 \mu \mathrm{g} /$

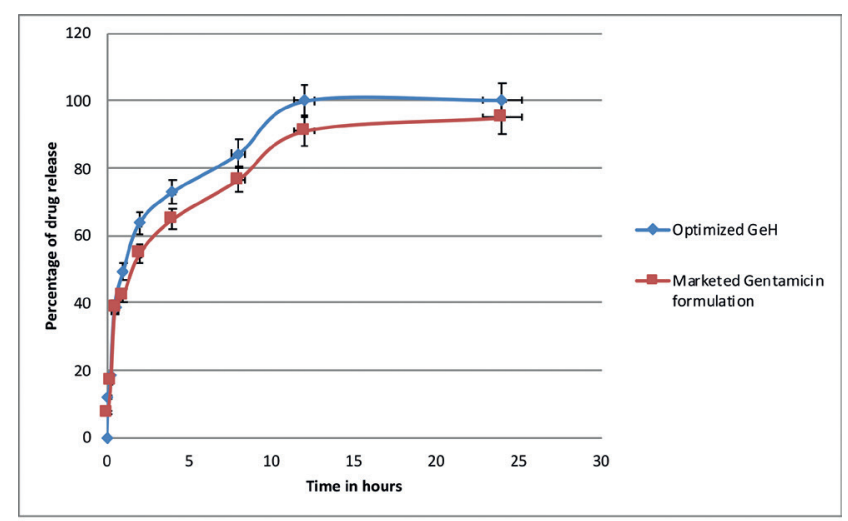

Figure 5 Comparison of percentage of gentamicin release from the optimised hydrogel fromulation and marketed gentamicin topical formulation against time in hours

Table 8. Accelerated stability testing on the optimized $(\mathrm{GeH})$ gentamicin hydrogel at $40^{\circ} \mathrm{C} / 75 \% \mathrm{RH}(\mathrm{p} \leq 0.05)$

\begin{tabular}{lllllll} 
Duration & $\mathrm{pH}$ & Assay (\%) & Gel index & Flux & $\begin{array}{c}\text { Drug permeation after } \\
12 \text { hours }\left(\mu \mathrm{g} / \mathrm{cm}^{2}\right)\end{array}$ \\
\hline Day 0 & $5.77 \pm 0.05$ & $99.65 \pm 0.11$ & $1.93 \pm 0.02$ & $15.93 \pm 0.22$ & $254.03 \pm 1.01$ & Satisfactory \\
\hline Day 10 & $5.79 \pm 0.04$ & $99.73 \pm 0.28$ & $1.96 \pm 0.03$ & $15.83 \pm 0.74$ & $251.72 \pm 2.11$ & Satisfactory \\
\hline Day 15 & $5.78 \pm 0.32$ & $99.43 \pm 0.78$ & $1.99 \pm 0.01$ & $16.09 \pm 0.32$ & $253.32 \pm 0.93$ & Satisfactory \\
\hline Day 30 & $5.78 \pm 0.07$ & $100.02 \pm 0.21$ & $1.96 \pm 0.01$ & $15.99 \pm 0.18$ & $250.11 \pm 1.02$ & Satisfactory \\
\hline Day 90 & $5.76 \pm 0.03$ & $99.98 \pm 0.03$ & $1.93 \pm 0.04$ & $15.93 \pm 0.07$ & $254.2 \pm 0.97$ & Satisfactory \\
\hline
\end{tabular}


$\mathrm{cm}^{2}$ compared with $176 \mu \mathrm{g} / \mathrm{cm}^{2}$ for the marketed formulation. The results are in consonance with the optimized values given in Table 7 from CCD with the solubilizing effect of the permeation enhancer/antioxidant ratio ensuring optimal flux and transdermal permeation within 12 hours at $60 \mathrm{rpm}$. All the gel formulations were stable at room temperature and under stressed conditions, as shown in Table 8, after accelerated stability testing.

\section{CONCLUSIONS}

Optimisation of gentamicin hydrogel using central composite statistical design is valid for the prediction of drug permeation and flux using variables in formulation preparation i.e. stirring speed and permeation enhancer:antioxidant ratio, thus showing their interaction with each other. The contour plots aided in the prediction of the value of transcutol:EETC and stirring speed, which would provide an optimized gentamicin hydrogel with optimal and drug permeation after 12 hours. The evaluation of therapeutic efficacy in an animal model is recommended for further studies.

\section{ACKNOWLEDGEMENTS}

The authors would like to thank Drugfield Pharmaceuticals Limited (Ogun State, Nigeria) for the gift of Gentamicin sulphate, Metchem Limited (Mumbai India) for the gift of Carbopol ${ }^{\circledR}$ Ultrez 21 and Gattefosse (Cedex, France) for the gift of Transcutol ${ }^{\circledR}$.

Conflict of Interest: No conflict of interest was declared by the authors.

\section{REFERENCES}

1. Nnamani PO, Kenechukwu FC, Anugwolu CL, Attama AA. Evaluation of hydrogels based on Poloxamer 407 and polyacrylic acids for enhanced topical activity of gentamicin against susceptible infections. Tropical Journal of Pharmaceutical Research. 2014;13:1385-1391.

2. Gulrez SKH, Al-Assaf S, Phillips GO. Hydrogels: Methods of preparation, characterization and applications A. Carpi (Ed), Progress in molecular and environmental bioengineering - From analysis and modeling to technology applications, InTech Publisher; Rijeka, Croatia; 2011:117-150.

3. Goindi S, Narula M, Kalra A. Microemulsion-based topical hydrogels of tenoxicam for treatment of arthritis. AAPS PharmSciTech. 2016;17:597666.

4. Ajaiyeoba EO, Fadare DA. Antimicrobial potential of extracts and fractions of the African walnut-Tetracarpidium conophorum. Afr $J$ Biotechnol. 2006;5:2322-2325.

5. Amaeze OU, Ayoola GA, Sofidiya MO, Adepoju-Bello AA, Adegoke AO, Coker HA. Evaluation of antioxidant activity of Tetracarpidium conophorum (Müll. Arg) Hutch \& Dalziel Leaves. Oxid Med Cell Longev. 2011;2011:976701.
6. Ezealisiji KM, Omotosho AE, Udoh R, Agbo MO. Wound healing activity of $\mathrm{N}$-hexane and methanol extracts of Tetracarpidium conophorum (Mull. Arg) Hutch. (African walnut) in wistar rats. Malaysian Journal of Pharmaceutical Sciences. 2014;12:79-88.

7. Hasatsri S, Yamdech R, Chanvorachote P, Aramwit P. Physical and biological assessments of the innovative bilayered wound dressing made of silk and gelatin for clinical applications. J Biomater Appl. 2015;29:1304-1313.

8. Amenaghawon NA, Osemwengie SO, Omoregbe O, Asogwa UJ. Application of experimental design method for the optimisation of xanthan gum production from pineapple peels using Xanthomonas campestris via submerged fermentation. Nigerian Journal of Technology. 2015;34:491-498.

9. Gopinadh R, Ayyanna C, Ramakrishna CH, Narayana SKV, Ravi VK, Jagadhi R. Optimization of Chemical Parameters for the Production of Citric acid using Box-Behnken Design. J Bioprocess Biotech. 2015;5:1-6.

10. Thongdumyu $\mathrm{P}$, Intrasungkha $\mathrm{N}$, Thong SO. Optimization of ethanol production from food waste hydrolysate by co-culture of Zymomonas mobilis and Candida shehatae under non-sterile condition. Afr $J$ Biotechnol. 2014;13:866-873.

11. Ilomuanya M, Billa N, Uboh C, Ifudu N, Ciallella J, Igwilo C. Formulation and characterization of activated charcoal and metronidazole layered tablets and evaluation of the in vivo performance of metronidazole Activated charcoal formulation in Sprague Dawley ${ }^{\circledR}$ rat model infected with Escherichia coli 0157:H7. International Journal of Pharmaceutical Sciences and Research 2017;8:45-59.

12. Kowalczuk D, Pietras R, Paw B, Czerkies A. Applying liquid chromatography with fluorescence detection to determine Gentamicin Polish J of Environ Stud. 2010;19:587-591.

13. Gannu R, Yamsani VV, Yamsani MR. Enhancement potential of Aloe vera on permeation of drugs with diverse lipophilicites across rat abdominal skin. Curr Trends Pharm Biotechnol. 2008;2:548-554.

14. Gethin G. The significance of surface pH in chronic wound Wounds UK; 2007:3:51-53

15. Amenaghawon NA, Osarumwense JO, Oti EO. Experimental design method for the production of bonded particleboards with optimum mechanical properties using sawdust. Journal of Civil, Construction and Environmental Engineering. 2016;14:73-82.

16. Montgomery DC. Design and Analysis of Experiments. 6. ed. New York; John Wiley \& Sons, Inc; 2005.

17. Cao G, Ren N, Wang A, Lee DJ, Guo W, Liu B, Feng $Y$, Zhao $Q$. Acid hydrolysis of corn stover for biohydrogen production using Thermoanaerobacterium thermosaccharolyticum W16. International Journal of Hydrogen Energy. 2009;34:7182-7188.

18. Lu Z, Fassihi R. Influence of colloidal silicon dioxide on gel strength, robustness, and adhesive properties of diclofenac gel formulation for topical application. AAPS PharmSciTech. 2015;16:636-644.

19. Gannu R, Yamsani VV, Yamsani SK, Palem CR, Yamsani MR. Optimization of hydrogels for transdermal delivery of lisinopril by Box-Behnken statistical design AAPS PharmSciTech. 2009;10:505-514. 